\title{
Effect of Dexamethasone and Pheniramine Maleate in Patients Undergoing Elective Laparoscopic Cholecystectomy
}

\author{
Binod Bade Shrestha, ${ }^{1}$ Mikesh Karmacharya, ${ }^{1}$ Binod Babu Gharti, ${ }^{1}$ Bishowdeep Timilsina, ${ }^{1}$ Pradeep Ghimire ${ }^{1}$ \\ 'Department of Surgery, Manipal College of Medical Sciences, Kaski, pokhara, Nepal.
}

\section{ABSTRACT}

Introduction: Laparoscopic cholecystectomy (LC) is elective surgical procedure for uncomplicated gallstone disease and gallbladder polyp. The objective of this study was to assess the efficacy of Dexamethasone and Pheniramine hydrogen maleate on reducing stress response and pain after surgery in patients undergoing laparoscopic cholecystectomy.

Methods: After obtaining approval from the institutional ethics committee and written informed consent, 120 patients undergoing elective laparoscopic cholecystectomy were enrolled in the study from Sep 2103 to Aug 2014 at Department of Surgery, Manipal College of Medical Sciences, Pokhara, Nepal. Patients were randomized to receive either $8 \mathrm{mg} / 2 \mathrm{ml}$ of Dexamethasone $+45.5 / 2 \mathrm{ml}$ Pheniramine hydrogen maleate (treatment group, $\mathrm{n}=60$ ) or $5 \mathrm{ml}$ of normal saline (control group, n=60) 90 minutes before skin incision.

Results: There was a reduction of total bilirubin, C-reactive protein (CRP) value and Visual Analogue Score (VAS) in treatment group as compared to control group $(\mathrm{p}<0.05)$.

Conclusions: Use of Dexamethasone and Pheniramine hydrogen maleate prior to surgical skin incision helps to reduce both postoperative pain and acute physiological stress.

Keywords: C - reactive protein; dexamethasone; laparoscopic cholecystectomy; pheniramine hydrogen

maleate.

\section{INTRODUCTION}

Laparoscopic cholecystectomy has been elective surgical procedure for uncomplicated gallstones and gallbladder polyp even in eastern developing countries. Increase recovery occurs with decrease discomfort, resulting from small skin incision and an early discharge. Minimal access approach also improves peri-operative respiratory function and diminishes catabolic response to surgery.
In normal patient, acute physiological stress induced by surgery and trauma activates hypothalamic pituitaryadrenal (HPA) axis, and a protective physiological response ensues. ${ }^{1}$ Acute phase proteins increase with trauma and sepsis and are released into the circulation as a part of the metabolic response to trauma. C- reactive protein (CRP), stress hormones and inflammatory

Correspondence: Dr. Binod Bade Shrestha, Manipal College of Medical Sciences, phulbari-11, Kaski, pokhara, Nepal. E-mail: badebinod@hotmail.com, Phone: +977-9841308692. 
Shrestha et al. Effect of dexamethasone and pheniramine in patients undergoing elective...

cytokines are important pathophysiological mediators associated with surgery. ${ }^{2}$ CRP is a major component of the acute- phase response which indicates inflammatory response.

The objective of this study is to see the effect of Dexamethasone and Pheniramine in post-operative pain and systemic acute phase response after elective laparoscopic cholecystectomy.

\section{METHODS}

After the approval from the local ethics committee and with written informed consent from each patient, 120 patients undergoing elective LC for symptomatic gallstone and gallbladder polyp with negative CRP diagnosed on the basis of clinical symptoms and ultrasonography were included in this study. This prospective randomized study was a single blind (patients were blinded regarding the treatment group or control group) trial. Randomization was done using computer generated random number table. Patients were recruited from October 2103 to September 2014 at department of surgery, Manipal College of Medical Sciences, Pokhara, Nepal.

The exclusion criteria included; American society of Anesthesiology (ASA) physical class $>2$, age $<17$ or $>75$ years, history of diabetes mellitus, alcohol or opium use, renal or liver failure, concomitant disease with nausea and vomiting, antacid use, pregnancy, antidepressant use, calcium channel blocker, immunological disease and treatment with steroids.

A total of 120 patients were randomized to receive either $8 \mathrm{mg} / 2 \mathrm{ml}$ of Dexamethasone $+45.5 / 2 \mathrm{ml}$ Pheniramine hydrogen maleate, Avil (Treatment Group, $n=60$ ) or saline $5 \mathrm{ml}$ (Control group, $\mathrm{n}=60$ ) intravenously, 90 minutes before skin incision. (Fig 1) All patients received prophylactic injection cefazoline $1 \mathrm{gm}$ iv after induction of general anesthesia.

A balanced general anesthesia using morphine $0.1 \mathrm{mg} /$ $\mathrm{kg}$, propofol 2-3mg/kg and vecuronium $0.1 \mathrm{mg} / \mathrm{kg}$ was used during induction. Towards the end of surgery all patients were given $4 \mathrm{mg}$ ondansetron and $30 \mathrm{mg}$ ketorolac. . Residual muscle paralysis was reversed using neostigmine $0.05 \mathrm{mg} / \mathrm{kg}$ and glycopyrrolate 0.01 $\mathrm{mg} / \mathrm{kg}$.

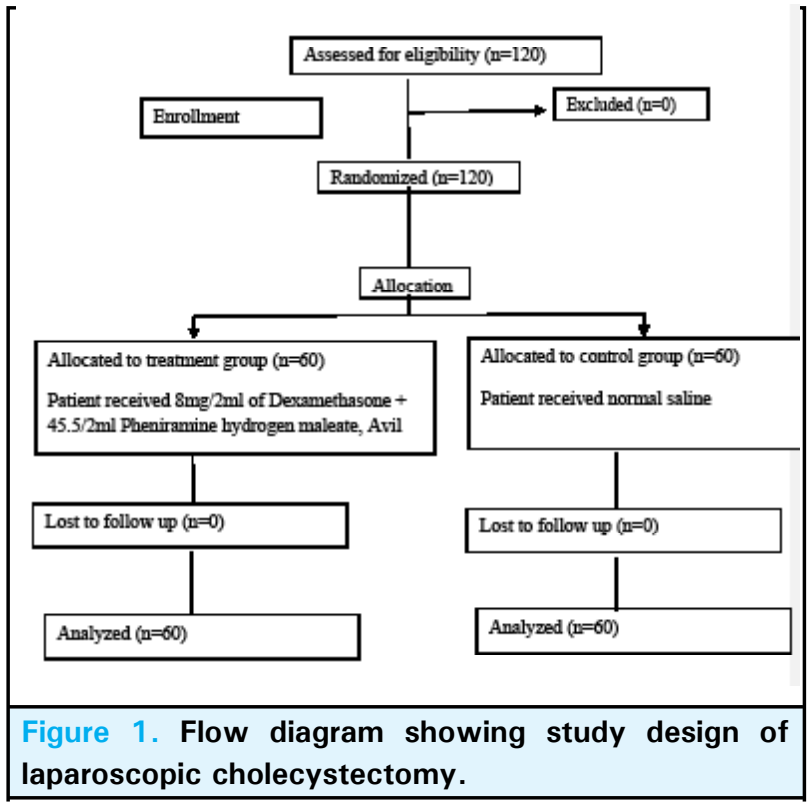

Carboperitoneum was created with a closed veress needle technique with a gas flow rate of 2 liters/min and LC was performed with standard four ports, two ports of $10 \mathrm{~mm}$ and two of $5 \mathrm{~mm}$ with reusable stainless steel trocars. Intraabdominal pressure was maintained at $10 \mathrm{mmHg}$. In case of multiple GB calculi, GB along with calculi was retrieved by sterile plastic bag. Carbon dioxide was carefully evacuated at the end of procedure and nasogastric tube was removed before transferring to the postoperative surgical ward. Two $10 \mathrm{~mm}$ port sites sheath was opposed with port closure polysorb 2-0. No local anesthesia was instilled in port sites.

The postoperative medication given to all patients was standardized using injection Cefazoline $1 \mathrm{gm} \mathrm{IV}$ 12 hourly, injection ketorolac 30mg every 8 hour and injection pantoprazole $40 \mathrm{mg}$ once daily for antiulcer prophylaxis. Oral intake was allowed after 6 hours on gaining consciousness.

On next early morning iv medications were changed to oral medications with tab pantoprazole $40 \mathrm{mg}$ od, tab ketorolac $10 \mathrm{mg}$ po tds and injection cefazoline was stopped. Blood samples were taken to measure Complete Blood Counts (CBC), liver function test (LFT), and CRP. Pain was also measured on the visual analog scale (VAS) with 0 point indicating no pain and 10 point indicating the worst pain experienced by the patient.

Data analysis was performed using SPSS for windows version 17. Data were shown as mean \pm standard deviation or median where applicable. The statistical significance of pre and postoperative measurement was evaluated by the student $t$ test for normally distributed data. A $p$ value $<0.05$ was considered statistically significant. 


\section{RESULTS}

Hundred twenty patients who underwent elective LC were enrolled (Table-1). Female predominance was noticed in both groups with total of $77 \%$ ( Table -2). The distribution of age among the group was not statistically significant (Table -2). The mean operative time was $81.69 \pm 29.36$ [min-max; 35-180] minutes. There was no significant difference between the groups according to the operative time (Table -2). One patient from treatment group had bile leak from the cystic duct stump which was taken care with ERCP and common bile duct stenting.

\begin{tabular}{|lll|}
\hline \multicolumn{3}{|l|}{ Table 1. Diagnosis of the patients in different } \\
\hline Diagnoups. & $\begin{array}{l}\text { Treatment } \\
\text { (Dexamethasone + Avil) }\end{array}$ & Control \\
$\begin{array}{l}\text { Symptomatic } \\
\text { cholelithiasis }\end{array}$ & 48 & 49 \\
$\begin{array}{l}\text { Acute calculus } \\
\text { cholecystitis }\end{array}$ & 4 & 3 \\
$\begin{array}{l}\text { Chronic calculus } \\
\text { cholecystitis }\end{array}$ & 5 & 7 \\
Gallbladder polyp & 3 & 1 \\
\hline
\end{tabular}

\begin{tabular}{|c|c|c|c|}
\hline Groups & $\begin{array}{l}\text { Age } \\
\text { (mean } \pm \\
\text { SD) }\end{array}$ & $\begin{array}{l}\text { Male / } \\
\text { Female }\end{array}$ & $\begin{array}{l}\text { Duration } \\
\text { of surgery } \\
\text { (mean } \pm \\
\text { SD) }\end{array}$ \\
\hline $\begin{array}{l}\text { Treatment } \\
\text { (Dexamethasone } \\
+ \text { Avil) }\end{array}$ & $\begin{array}{l}42.48 \\
\pm 12.135\end{array}$ & $12 / 48$ & $\begin{array}{l}80.58 \pm \\
27.618\end{array}$ \\
\hline Control & $\begin{array}{l}44.7 \pm \\
14.979\end{array}$ & $16 / 44$ & $\begin{array}{l}82 \pm \\
31.189\end{array}$ \\
\hline $\mathrm{P}$ value & 0.3742 & & 0.6805 \\
\hline
\end{tabular}

The comparison of pre- and postoperative difference in hemoglobin, AST and ALT among the groups were not statistically significant (Table-3). The comparison of preoperative difference in WBC count was not significant among the group. However, postoperative increase in WBC count among the group was statistically significant $(p=0.035)$ more being on treatment group.

The comparison of pre- and postoperative difference between the group in platelet count showed $p=0.345$ and $p=0.035$ respectively. This shows significant decrease in platelet count among the group postoperatively (Table- 3).Likewise there was significant rise in bilirubin level $(p=0.007)$ in comparison of postoperative difference in total bilirubin (Table -3).

Table 3. Pre and post-operative Biochemical laboratory measurement.

\begin{tabular}{|l|l|l|l|l|}
\hline Variables & $\begin{array}{l}\text { Preoperative } \\
\text { Mean } \pm \text { SD }\end{array}$ & $\begin{array}{l}\text { Postoperative } \\
\text { Mean } \pm \text { SD }\end{array}$ & $\begin{array}{l}\text { P value with diff group } \\
\text { Within pre }\end{array}$ & $\begin{array}{l}\text { P value } \\
\text { Post }\end{array}$ \\
\hline WBC & & & & $0.035^{*}$ \\
Treatment & $7771.17 \pm 2193.894$ & $12053.33 \pm 3547.42$ & 0.916 & \\
Control & $7730 \pm 2069.332$ & $10773.33 \pm 3013.85$ & & 0.299 \\
\hline Hb\% & $12.18 \pm 1.39$ & $11.34 \pm 1.22$ & 0.172 & \\
Treatment & $12.53 \pm 1.39$ & $11.58 \pm 1.29$ & & \\
Control & $245562.5 \pm 82207.29$ & $223100 \pm 56397.34$ & & \\
\hline Platelet & & & & \\
Treatment & $258911.1 \pm 71652.83$ & & & \\
Control & $244787.23 \pm 55105.01$ & 0.345 & \\
\hline
\end{tabular}




\begin{tabular}{|l|l|l|l|l|}
\hline AST & & & & \\
Treatment & $26.55 \pm 11.78$ & $41.57 \pm 24.87$ & 0.278 & 0.127 \\
\hline ALT & $32.17 \pm 38.22$ & $51.77 \pm 45.11$ & \\
Treatment & $30.12 \pm 22.13$ & $39.47 \pm 22.82$ & 0.773 & 0.134 \\
Control & $31.45 \pm 28.07$ & $49.77 \pm 47.68$ & & \\
\hline T. Bilirubin & & $1.18 \pm 0.55$ & 0.059 & $0.007^{*}$ \\
Treatment & $0.76 \pm 0.38$ & $1.6 \pm 1.06$ & & \\
Control & $0.94 \pm 0.62$ & $43.92 \pm 28.61$ & & \\
\hline CRP & Negative & $55.9 \pm 25.46$ & & \\
Treatment & Negative & & \\
Control
\end{tabular}

$\mathrm{WBC}=$ whole blood count, $\mathrm{Hb} \%=$ hemoglobin, $\mathrm{AST}=$ Aspartate aminotransferase, ALT = Alanine transaminase, $\mathrm{CRP}=\mathrm{C}$-reactive protein,${ }^{*}$ significant $\mathrm{p}$ value

The post-operative comparison difference in CRP showed significant increase in Control group $(p=0.016)$ [Table-3]. The VAS score for pain was significantly higher in control group when compared with treatment group $(p<0.0001)$ [Table-4].

\begin{tabular}{|c|c|}
\hline Groups & VAS $($ mean $\pm S D)$ \\
\hline $\begin{array}{l}\text { Treatment (Dexamethasone + } \\
\text { Avil) }\end{array}$ & $3.98 \pm 1.478$ \\
\hline Control & $5.3 \pm 0.829$ \\
\hline$P$ value & $<0.0001 *$ \\
\hline
\end{tabular}

VAS $=$ Visual Analogue Score, ${ }^{*}$ significant $p$ value

\section{DISCUSSION}

Dexamethasone, a glucocorticoid group drug is known for antiemetic, analgesic, and anti-inflammatory effects, which biological action begins after 1-2 hours of administration.$^{3}$ The effects are probably mediated by inhibition of both prostaglandin synthesis and endogenous opioid release centrally . ${ }^{4}$ Various studies regarding the same has shown to reduce emesis after surgical operation and LC. It has also shown to reduce pain, fatigue, opioid use and vomiting. ${ }^{5}$ Pheniramine hydrogen maleate, an $\mathrm{H} 1$ receptor antagonist usually used as a potent anti-allergic drug significantly reduces
PONV in postoperative patients. ${ }^{6}$

Dexamethasone was first noticed to be effective in patients under chemotherapy. ${ }^{7}$ Several studies have shown that Dexamethasone improves surgical outcome after laparoscopic cholecystectomy by reducing disabling symptoms. However, there are studies which conclude higher doses of Dexamethasone $(8-16 \mathrm{mg}$ ) are more effective than smaller doses $(2-5 \mathrm{mg}) .^{8}$

A study done by CV Feo et al showed no reduction in postoperative pain or analgesic requirements in patients receiving Dexamethasone. ${ }^{9}$ However, there are papers published in contrast to it. ${ }^{10}$ Dexamethasone decreases the production of cyclooxygenase and lipoxygenase pathway. ${ }^{11}$ Avil (Pheniramine hydrogen maleate), $\mathrm{H} 1$ antagonist has a role in central pain processing. Dexamethasone along with Pheniramine maleate may have a synergistic action on reduction of postoperative pain. In this present study the treatment group has offer better pain relief.

In the present study, there was no significant difference in pre and postoperative comparison among the group in hemoglobin, AST and ALT. Although there was a significant decrease in total bilirubin, platelet count and CRP value postoperatively. There was significant increase in WBC count postoperatively. The increase in WBC was seen more in treatment group than Control group. 


\section{CONCLUSIONS}

In conclusion our study shows that Dexamethasone when used along with Pheniramine hydrogen maleate have a promising effect on reducing the postoperative pain and systemic acute phase response after laparoscopic cholecystectomy. With respect to control group there was no impaired wound healing, postoperative infection or other complication on treatment group leading to impaired surgical outcome after LC.

\section{REFERENCES}

1. Chernow B, Alexander HR, Thompson WR et al (1987) The hormonal response to surgical stress. Arch Intern Med 147(7): 1273-1278

2. Sido B, Teklote JR, Hartel $M$ et al (2004) Inflammatory response after abdominal surgery. Best Pract Res Clin Anaesthesiol 18(3): 439-454

3. Sapolsky RM, Romero LM, Munck AU (2000) How do glucocorticoids influence stress responses? Integrating permissive, suppressive, stimulatory, and preparative actions. Endocr Rev 21: 55-89

4. Holte K, Kehler H (2002)Perioperative single dose glucocorticoid administration: pathophysiologic effects and clinical implications. J Amer Coll of Surg 195:694-712

5. Lopez-Olaondo L, Carrascosa F, Pueyo FJ, Monedero P, Busto N, Saez A (1996) Combination of ondansetron and dexamethasone in the prophylaxis of postoperative nausea and vomiting. Br J Anaesth 76:835-840

6. Doenicke AW, Hoernecke R, Celik I (2004) Premedication with $\mathrm{H} 1$ and $\mathrm{H} 2$ blocking agents reduces the incidence of postoperative nausea and vomiting. Inflamm Res 2004;53(suppl 2):S154 -158
7. Aapro MS, Alberts DS (1981) Dexamethasone as an antiemetic in patients treated with cisplatin. N Engl J Med 305(9):520

8. Paul J. Karanicolas PJ,Smith SE, Kanbur B, Davies E,Guyatt GH The Impact of Prophylactic Dexamethasone on Nausea and Vomiting After Laparoscopic Cholecystectomy A Systematic Review and Meta-Analysis. (2008) Ann Surg 248:751-762

9. Feo CV, Sortini D, Ragazzi R, Palma MD, Liboni A (2006) Randomized clinical trial of the effect of preoperative dexamethasone on nausea and vomiting after laparoscopic cholecystectomy. Br J Surg 93:295-299

10. Elhakim M, Nafie M, Mahmoud K, Atef A (2002) Dexamethasone $8 \mathrm{mg}$ in combination with ondansetron $4 \mathrm{mg}$ appears to be the optimal dose for the prevention of nausea and vomitingafter laparoscopic cholecystectomy. Can J Anaesth 49: 922-926

11. Sapolsky RM, Romero LM, Munck AU (2000) How do glucocorticoids influence stress responses? Integrating permissive, suppressive, stimulatory, and preparative actions. Endocr Rev 21:55- 89 